\section{DIGITAL COMMONS \\ @ UNIVERSITY OF SOUTH FLORIDA}

\section{ABO: Interactive Journal for Women in the Arts, 1640-1830}

Volume 2

Issue 1 Volume 2.1 (Spring 2012): Open Access

Article 14

2012

\title{
In Search of Lady Isabella's Library; or, A Question of Access
}

Patricia L. Hamilton

Union University, phamilto@uu.edu

Follow this and additional works at: https://digitalcommons.usf.edu/abo

Part of the Dramatic Literature, Criticism and Theory Commons, Educational Methods Commons, Feminist, Gender, and Sexuality Studies Commons, and the Literature in English, British Isles Commons

\section{Recommended Citation}

Hamilton, Patricia L. (2012) "In Search of Lady Isabella's Library; or, A Question of Access," ABO:

Interactive Journal for Women in the Arts, 1640-1830: Vol.2: Iss.1, Article 14.

http://dx.doi.org/10.5038/2157-7129.2.1.13

Available at: https://digitalcommons.usf.edu/abo/vol2/iss1/14

This New Media is brought to you for free and open access by Digital Commons @ University of South Florida. It has been accepted for inclusion in ABO: Interactive Journal for Women in the Arts, 1640-1830 by an authorized administrator of Digital Commons @ University of South Florida. For more information, please contact digitalcommons@usf.edu. 


\section{In Search of Lady Isabella's Library; or, A Question of Access}

\section{Keywords}

access, archives, Charlotte Lennox, digital archives, literary influence, online databases, women's education

Creative Commons License (c) (1) $\ominus$

This work is licensed under a Creative Commons Attribution-No Derivative Works 3.0 License. 
Over the past thirty years, scholars have suggested that Charlotte Lennox drew on a variety of sources to shape The Female Quixote. Some of these, such as Cervantes's Don Quixote, the romances of Scudéry and La Calprenède, and Boyle's Parthenissa, are self-evident within the novel. Others, such as Shakespeare's The Tempest, Fénelon's Traité de l'éducation des filles, or Locke's An Essay Concerning Human Understanding, are based on speculation rather than hard evidence. ${ }^{1}$ Still others fall somewhere between these two poles. ${ }^{2}$ When we tally up the texts that have been proposed as influences on The Female Quixote, we find they number no fewer than seventeen and represent at least thirteen different writers (Appendix A). This fact raises an interesting question: How did Lennox, who was only twenty-two or twenty-three when her novel was published, gain access to these texts?

The question becomes even more interesting if we consider the texts mentioned in Lennox's first novel, The Life of Harriot Stuart, Written by Herself, published in late 1750 when Lennox was about twenty. Works that Lennox either quotes or refers to directly number eight (Appendix B), and she mentions an additional six writers by name (Appendix C). Of the fourteen different writers alluded to in Harriot Stuart, only one, Madeleine de Scudéry, appears on our list of possible influences on The Female Quixote (Appendix D). This brings the non-duplicating headcount of writers with whom Lennox was likely familiar to twenty-six. To this number we can add at least four more: Ovid, Sappho, George Farquhar, and Joseph Addison. Lennox's Poems on Several Occasions, published in 1747 when Lennox was about seventeen, contains poems entitled "A Hymn to Venus, in Imitation of Sapho" and "An Ode, in Imitation of Sapho" as well as "A Parody on an Ode of Horace, as Translated by Mr. Farquhar." The volume's final poem, "Shallum to Hilpah, an Epistle from the Spectator," is a versification of Addison's Spectator No. 584 (Small 156). Poems on Several Occasions also contains verses entitled "An Epistle to Moneses, in Imitation of Ovid” and “A Pastoral, from the Song of Solomon.” By the time Lennox was twenty-three, then, she had referenced the works of approximately thirty writers plus the biblical book "Song of Solomon" in her own publications (Appendix E). ${ }^{3}$

Thus, to our original question, "How did Lennox gain access to the texts she read?” we might add, "How did she develop a familiarity with such a wide array of writers?” They cover a broad spectrum, from ancients such as Homer, Plato, and Cicero, to moderns such as Pope and Prior; from Anglican divines such as Chillingworth, Barrow, and Tillotson, to the philosopher Francis Hutcheson. What little we know about Lennox's childhood and youth makes these questions all the more intriguing. The daughter of a British army captain, young Charlotte lived in Albany and Schenectady, New York, from approximately 1739 to 1742. After her father's death on March 10, 1742, she was sent home to England to live with her mother's sister, but her aunt became incapacitated and soon died (Carlile 112-13). Here the biographical record grows murkier, but a memoir of Lennox published in The British Magazine and Review in 1783 indicates that Lady Isabella Finch, first Lady of the Bedchamber to Princess Amelia, and Finch's sister, Lady Rockingham, took an interest in Charlotte until her marriage to Alexander Lennox on Oct. 6, 1747 ("Mrs. Lennox" 207). Lady Isabella lived at 44 Berkeley Square in a house that architect William Kent finished building for her in 1744 (Chalus 571). According to Lady Mary Wortley Montagu, "Bell” Finch was "the only Lady at Court" to have her own library (8).

The suggestive nature of this last fact has long stirred my imagination: What was in Lady Isabella's library? Susan Staves has noted that "[m]ost successful eighteenth-century women 
writers had unusual access to good private libraries” (“Books” 199). We may naturally wonder what reading matter was available to young Charlotte up until her family’s departure for New York as well as how her access to books changed after their relocation. But it is even more provocative to consider what books the adolescent Charlotte Lennox might have had access to in Lady Isabella's library between approximately 1744 and late 1747 . If we could establish that Lady Isabella owned copies of the works by Fénelon and Locke on our list of proposed influences on The Female Quixote, our scholarly speculations about these authors' impact on Lennox's thinking would be one step closer to confirmation. And did Lady Isabella own a copy of Mary Astell's A Serious Proposal to the Ladies or perhaps Steele's Ladies Library, which included excerpts from Astell's treatise? (Dammers 532-34). If so, we might reasonably posit that Astell influenced Lennox's thinking about women's mental and ethical development, since certain passages in The Female Quixote point in this direction.

My ruminations on Charlotte Lennox's access to books are offered as a reminder that women's intellectual history matters. By "intellectual history” I mean primarily the formation of women writers' minds - their understanding, judgment, beliefs, and values - through reading and conversation. But I would extend "formation" also to include what women saw performed on the stage, what music they heard, and what they viewed in terms of visual art, architecture, and landscape. In any case, a simple listing of works Lennox is believed to have read by 1752 goes a long way, I think, toward rehabilitating her characterization by well-meaning scholars of earlier generations as the weak-minded dependent of Samuel Johnson and Samuel Richardson and toward reinforcing the more accurate picture of Lennox's capabilities that has been steadily emerging from careful critical examination of her work.

Questions regarding writers' access to texts in the eighteenth century invite us to consider issues of access in our own time, especially those faced by literary scholars working on women writers of the long eighteenth century. In the mid-twentieth century, the twin critical projects of recovering the works of certain eighteenth-century male writers (the cottage industry of Defoe attribution and de-attribution comes to mind) and of rescuing the reputations of other male writers from dismissive nineteenth-century critical judgments ${ }^{4}$ resulted in a number of important literary biographies and fostered a concomitant interest in intellectual history. Feeding this biographical and historical effort were many attempts to identify specific literary influences on the writers under consideration. Titles such as “Another Book Owned by Samuel Johnson” appeared in publications such as Notes and Queries (Sherbo). However, this type of scholarly work was no doubt often slow and tedious due to the physical difficulties involved in accessing and assessing archival materials.

Today, literary scholars engaged in recovering women writers' texts and intellectual history face different limitations and opportunities. Since girls were excluded from the formal educational establishment in the eighteenth century, women writers' intellectual development was necessarily a more individualized matter than that of university-educated male writers who shared the common body of knowledge covered by the quadrivium and the trivium. We must therefore look outside the eighteenth-century grammar school and university curricula to other materials that might suggest patterns behind women's reading habits and intellectual development. Fortunately, we have many aids - a diverse body of literary theory, studies in the history of the book, studies in material culture, literary histories of women's writing, and so on-to draw from as we seek to 
map the influences that shaped eighteenth-century women writers' opinions and beliefs and, in turn, their literary endeavors. Such a project is, of course, already well underway to the extent that various scholars are writing or updating literary biographies of eighteenth-century women writers.

Along with having a wealth of previously unavailable resources, we have an unprecedented opportunity to transcend creatively and collaboratively some of the physical barriers to access that previous generations of scholars faced. To that end, I want to propose that we engage in a more comprehensive, more networked attempt to retrieve, store, and share data whenever and wherever we come across it. To do this thoroughly and well, we need to create the information architecture that will serve the needs of the widest range of scholarship we can imagine. I suggest that we think in terms not only of a repository for data but also of a space where we can post queries, offer ideas, and make speculative connections-part database, part discussion list, part blogsite, the whole of it searchable and interactive.

Of primary concern is the need for increased virtual access to information. Today's problems of access have less to do with the gender issues eighteenth-century women writers faced than with economic constraints. While the "digital divide" may have shrunk in the general population over the last decade, in academics the gap between the "haves" and the "have-nots" has not been eliminated. Gale Cengage’s Eighteenth-Century Collections Online (ECCO) has fostered greater accessibility to eighteenth-century texts, but many scholars like myself work at universities that cannot afford an institutional subscription. This type of problem may eventually be resolved or at least ameliorated by the availability of individual subscriptions to databases such as that which the Cambridge Orlando Project offers or by the creation of specialized user groups whose members pay an annual fee to access particular databases. Still, in these days of recessionary budget cuts and increased teaching loads, many of us face the limitation shared by our scholarly forebears: increasingly few of us can muster the time and travel funding necessary to methodically sift through archival material in distant locations that has not yet been made accessible by digitization. However, someone who is already sifting through such material might come across data that would address the needs or even answer the queries of others, if only such needs and queries were known. Hence, the opportunity is ripe to think creatively together about how scholars doing archival research on women writers might collaborate.

The value of collaboration has been one of the most productive tenets of feminist scholarship. The Brown University Women Writer's Project, the Orlando Project, the Perdita Project, and other endeavors like these all give evidence of the benefits that pooling resources and networking can offer. Currently, however, there is no "project" dedicated to the intellectual history of women writers of the long eighteenth century. The right information architecture would allow us to expand our knowledge base about these writers' lives and intellectual development. Usable data might come from subscriptions lists, receipts, legal records or documents, letters, diaries, and squibs in periodicals. By "usable" I mean not only facts that point to specific cultural engagements or possible print influences_-books subscribed to, pamphlets shared, plays praised or denounced, sermons discussed - but also information that enlarges our knowledge of the social networks women writers operated within. Greater knowledge of such networks might provide insight into issues of patronage, mentorship, and formal or informal collaboration, not to mention access to texts. 
An excellent example of such a social-professional network can be found in Betty Schellenberg's recent essay, "Putting Women in Their Place: Women Novelists and London in the 1750s." Starting from a question concerning the whereabouts of a book, Schellenberg explores the evidence for a working relationship between Sarah Scott, Walter Harte, and Charlotte Lennox in 1759-60 and ends with a series of questions: "Did Lennox introduce Sarah Scott to Harte and to the idea of writing histories? Did Lennox help Harte stay connected with London professional circles while he was in 'exile' in Cornwall? Was she in turn hoping for access to Elizabeth Montagu through Scott? Was Lennox a source of information for Scott about her estranged husband?” (243-44). Schellenberg concedes we may never know the answers to these questions. But the salient point here about archival research is that information leading to answers is not apt to be found in obvious places, which Schellenberg would have already explored. A more likely scenario is that a scholar doing research on, say, Sarah Scott's sister, Elizabeth Montagu, may happen to have read Schellenberg's essay and thus be able to recognize a piece of the ScottHarte-Lennox puzzle if she stumbles across it in (hypothetically) the correspondence between two parties in Montagu's circle of influence. A scholar who happens to be acquainted with Betty Schellenberg may take the time to alert her to the discovery. Otherwise, the information is apt to remain a brief blip on the scholar's radar screen-noted, perhaps, but then lost from sight for lack of a reporting mechanism. Traditional means of sharing knowledge can be haphazard, to say the least.

The chances of capturing and using such blips of information could be multiplied exponentially, however, with a formal system in place for posting scholarly "BOLOs” and "sightings." In law enforcement, the initials B. O. L. O. stand for "be on the lookout," so a BOLO is the modern equivalent of an old-fashioned "wanted" poster. Information technology allows BOLOs to be electronically disseminated across geographic boundaries instantaneously. The greater the number of law enforcement personnel looking for a criminal, the higher the likelihood of sightings that will lead to the criminal's apprehension. Similarly, the greater the number of eighteenth-century scholars aware of Schellenberg's questions about the Scott-Harte-Lennox connection — or mine about the contents of Lady Isabella's library-the higher the likelihood that clues, if they exist, will be spotted.

But this brings up an important concern about intellectual property. Scholars-particularly those on the untenured or otherwise-marginalized end of the career spectrum-may be reluctant to share information in a communal setting for fear of having their work "scooped" or plundered by others without receiving credit. There is some validity to this fear. In fact, we all take risks in this arena when we present our works-in-progress at conferences. Let me therefore clarify the kind of information I am talking about sharing - namely, facts that may be helpful to others that we come across in the course of our research but that have no immediate or direct bearing on that research. I am not suggesting that people give away treasure troves of their own discovery. I am suggesting that if I were reading Bluestocking correspondence and happened across a reference that shed a little light on Walter Harte's working relationship with Sarah Scott, there would be no professional reason not to share it if all I had to do was type it into a series of electronic dialogue boxes. If I were uncertain as to whether my information was worth sharing, I could simply type "Scott and Harte” into a search engine and Schellenberg's query would pop up, along with any 
responses to date. Even if no queries had been posted, I could still elect to share my discovery. In either case, the entire process might take only ten minutes.

My underlying premise, of course, is that facts in and of themselves are not proprietary and should not be treated as such. It is not upon mere facts but upon the interpretation of facts that scholarly careers are built. Moreover, facts in isolation do not signify much. A recent check of Google Scholar revealed that Lady Isabella Finch subscribed to the following five works: Lewis Theobald's 1733 edition of The Works of Shakespeare; Jus Parliamentarium by William Petyt, published in 1739; The History of the Popes, from the Foundation of the See of Rome to the Present Time by Archibald Bower, published in 1750; Elizabeth Carter's 1758 translation of the works of Epictetus; and The Antiquities of Athens by James Stuart and Nicholas Revett, published in 1762. This "open access" information may bring me five books closer to identifying the contents of Lady Isabella's library, but only the first work in the list has any bearing on the question of Charlotte Lennox's access to books, and its discovery does not offer a sufficient basis for a scholarly monograph. I lose nothing by sharing it with others.

I suspect that our moving the give-and-take of scholarly information-sharing to the electronic environment would invoke the self-regulatory ethos shared by the "open source" community. The goal of such an ethos is to foster a culture of generosity fueled by intellectual curiosity. In my observation, a community that functions on the basis of collegiality and trust already exists among various scholars specializing in eighteenth-century women writers. By becoming virtual, that community could become more inclusive and its benefits more accessible.

However, the question of credit being given where credit is due points to a second area of concern. With the pressure to publish continuing unabated in many quarters despite shrinking resources, untenured junior scholars might ask if they should be spending their energies on pursuits that do not directly lead to publication. It may be that the painstaking work of writing an extensive literary biography or intellectual history is best undertaken by someone with the protection that tenure provides. But everyone benefits from accurate biographical information, and the most recent and accurate information should be accessible to all, including undergraduates. By the same token, anyone who makes an important find should be able to share it. Since the virtual environment allows discrete units of data to be archived relatively easily, the often-lengthy traditional publication process can be strategically truncated for certain types of data. For the sake of all academic ranks, then, we should promote recognition among academic institutions that we are performing essential scholarly work when we are engaged in archival research and information sharing. We need to devise units of measure for valuing contributions to the common body of knowledge so that promotion and tenure committees acknowledge those contributions. Toward that end, the peer-review function being instituted by 18thConnect (the new online sister project to NINES: Nineteenth-Century Scholarship Online) for digital work in the eighteenth century would be important to explore. An "E-Notes and Queries" (with a conventional editorial apparatus) dedicated to the eighteenth century would also be an excellent vehicle for vetting archive-based scholarship. Certainly the new "Notes and Discoveries" section of $A B O$ will be an important first step toward information-sharing about women writers of the long eighteenth century. 
In terms of a searchable, contributor-driven online database, The Reading Experience Database (RED), 1450-1945 might serve as a useful model. The database for the UK-based version of the global project, housed at the Open University, currently contains over 30,000 records. In addition to offering users "search" and "browse" features (including the option of browsing by reader and browsing by author read), it includes a user-friendly "contribute” section with extensive explanatory notes and several downloadable sample completed RED forms that exemplify common issues a contributor might encounter. The "FAQ" page addresses questions on searching and browsing, contributing, and technical difficulties. One helpful feature is that the electronic RED form is clearly divided into a "mandatory information" section and two additional "optional information" sections for contributors who have more extensive knowledge about the source they are reporting on. Many of the data-collection questions are of the timesaving "check the box that applies" variety, which is useful for an open-source database with non-specialist contributors. However, the data-collection categories and questions for a database such as I am advocating for eighteenth-century specialists dealing with archival materials regarding women's intellectual history might need to be more open-ended. Any text boxes should have generous word-count allotments.

Literary critics have long been engaged with reconstructions of male writers' intellectual history. Expanding the focus to include female writers is simply a matter of equal opportunity. Perhaps our best strategy for advancing our work is to take the long view, extending not only forward in time but also backward. Looking back will remind us that eighteenth-century writers were aware, just as we are, that matters of cultural context and intellectual history were of primary importance to the interpretive enterprise. Donald Greene's book Samuel Johnson's Library attests to this fact by opening with a quotation from a letter written in 1754 from Johnson to Thomas Warton:

You have shown to all who shall hereafter attempt the study of our ancient authors the way to success, by directing them to the perusal of the books which those authors had read. ... The reason why the authors which are yet read of the sixteenth century are so little understood is that they are read alone, and no help is borrowed from those who lived with them or before them. Some part of this ignorance I hope to remove by my book. . . . (5)

What better ally for us to claim than Samuel Johnson - the friend, supporter, and colleague of women such as Charlotte Lennox, Elizabeth Carter, Hannah More, Elizabeth Montagu, Anna Williams, Hester Thrale Piozzi, and Frances Burney - to champion the cause of reconstructing eighteenth-century women writers' intellectual history?

Acknowledgment: The author wishes to thank Susan Carlile, Emily Friedman, and Devoney Looser for generously sharing their expertise in ways that enhanced the manuscript and to thank Jennie Batchelor and Aleksondra Hultquist for their encouragement. 


\section{Notes}

1. The connection to Shakespeare's The Tempest is made by Deborah Ross. Fénelon and Locke are discussed by Sharon Smith Palo, and Locke is discussed by Patricia L. Hamilton.

2. Perdou de Subligny’s La Fausse Clélie is discussed by Margaret Doody, David Marshall, and Devoney Looser; Steele's The Tender Husband by Doody; Marivaux's Don Quixote Moderne by Ronald Paulson and Susan Staves (“Don Quixote”); Henry Fielding's novels by Eric Rothstein and Mary Patricia Martin; and Richardson’s Clarissa by Joseph F. Bartolomeo. Critics who have treated Johnson's Rambler in conjunction with The Female Quixote include Patricia Meyer Spacks and Margaret Dalziel along with Marshall, Bartolomeo, and Looser.

3. Susan Kubica Howard makes a case for Lennox's also having been familiar with popular genres such as the Indian captivity narrative and tales of sea-faring adventure (43-57).

4. A representative example would be Thomas Babington Macaulay's shaping of Victorian perceptions of Samuel Johnson. See Clifford 46-48. 
Works Cited

$18^{\text {th }}$ Connect: Eighteenth-Century Scholarship Online. http://www.18thConnect.org. N. d. Web. 19 Nov. 2011.

Bartolomeo, Joseph F. “Female Quixotism v. 'Feminine’ Tragedy: Lennox’s Comic Revision of Clarissa.” New Essays on Samuel Richardson. Ed. Albert J. Rivero. New York: St Martin’s, 1996. 163-76. Print.

Carlile, Susan. "Expanding the Feminine: Reconsidering Charlotte Lennox's Age and The Life of Harriot Stuart.” The Eighteenth-Century Novel 4 (2004): 103-37. Print.

Chalus, E. H. "Finch, Lady (Cecilia) Isabella (1700-1771)." Oxford Dictionary of National Biography. Ed. H. C. G. Matthew and Brian Harrison. Vol. 19. Oxford: Oxford UP, 2004. Print.

Clifford, James L. “A Survey of Johnsonian Studies, 1887-1950.” Samuel Johnson: A Collection of Critical Essays. Ed. Donald J. Greene. Englewood Cliffs, NJ: PrenticeHall, 1965. 46-62. Print.

Dalziel, Margaret. Explanatory notes. The Female Quixote; or, The Adventures of Arabella. By Charlotte Lennox. Ed. Margaret Dalziel. Oxford: Oxford UP, 1989. 388-418. Print.

Dammers, Richard H. "Richard Steele and The Ladies Library.” Philological Quarterly 62.4 (1983): 530-36. Print.

Doody, Margaret Anne. Introduction. The Female Quixote; or, The Adventures of Arabella. By Charlotte Lennox. Ed. Margaret Dalziel. Oxford: Oxford UP, 1989. xi-xxxii. Print.

Greene, Donald. Samuel Johnson’s Library: An Annotated Guide. Victoria, BC: English Literary Studies, U of Victoria, 1975. Print.

Hamilton, Patricia L. “Arabella Unbound: Wit, Judgment, and the Cure of Charlotte Lennox's Female Quixote.” Masters of the Marketplace: British Women Novelists of the 1750s. Ed. Susan Carlile. Bethlehem: Lehigh UP, 2011. 108-27. Print.

Howard, Susan Kubica. Introduction. The Life of Harriot Stuart, Written by Herself. By Charlotte Lennox. Ed. Susan Kubica Howard. Madison, NJ: Fairleigh Dickinson UP, 1995. 13-57. Print.

Lennox, Charlotte. The Female Quixote; or, The Adventures of Arabella. Ed. Margaret Dalziel. Oxford: Oxford UP, 1989. Print.

---. The Life of Harriot Stuart, Written by Herself. Ed. Susan Kubica Howard. Madison, NJ: Fairleigh Dickinson UP, 1995. Print. 
---. Poems on Several Occasions. London: S. Paterson, 1747. Print.

Looser, Devoney. British Women Writers and the Writing of History, 1670-1820. Baltimore: Johns Hopkins UP, 2000. Print.

Marshall, David. "Writing Masters and 'Masculine Exercises' in The Female Quixote.” Eighteenth-Century Fiction 5.2 (1993): 105-35. Print. http://dx.doi.org/10.1353/ecf.1993.0022

Martin, Mary Patricia. “'High and Noble Adventures': Reading the Novel in The Female Quixote.” Novel 31.1 (1997): 45-62. Print. http://dx.doi.org/10.2307/1345965

"Mrs. Lennox.” The British Magazine and Review 3 (July 1783): 8-11. Rpt. in Sophia. By Charlotte Lennox. Ed. Norbert Schürer. Peterborough, ON: Broadview, 2008. 205-11. Print.

Palo, Sharon Smith. "The Good Effects of a Whimsical Study: Romance and Women's Learning in Charlotte Lennox's The Female Quixote.” Eighteenth-Century Fiction 18.2 (2005-06): 203-28. Print. http://dx.doi.org/10.1353/ecf.2006.0030

Paulson, Ronald. Satire and the Novel in Eighteenth-Century England. New Haven: Yale UP, 1967. Print.

The Reading Experience Database (RED), 1450-1945. UK RED. The Open University. N. d. Web. 19 Nov. 2011.

Ross, Deborah. “Mirror, Mirror: The Didactic Dilemma of The Female Quixote.” SEL 27.3 (1987): 455-73. Print.

Rothstein, Eric. "Woman, Women, and The Female Quixote.” Augustan Subjects: Essays in Honor of Martin C. Battestin. Ed. Albert J. Rivero. Newark: U of Delaware P, 1997. 249-75. Print.

Schellenberg, Betty A. "Putting Women in Their Place: Women Novelists and London in the 1750s." Masters of the Marketplace: British Women Novelists of the 1750s. Ed. Susan Carlile. Bethlehem: Lehigh UP, 2011. 242-58. Print.

Sherbo, Arthur. “Another Book Owned by Samuel Johnson. Notes and Queries 31.3 (1984): 402-03. Print.

Small, Miriam Rossiter. Charlotte Ramsay Lennox: An Eighteenth-Century Lady of Letters. New Haven: Yale UP, 1935. Print.

Spacks, Patricia Meyer. "The Subtle Sophistry of Desire: Dr. Johnson and The Female Quixote.” Modern Philology 85.4 (1988): 532-42. Print. http://dx.doi.org/10.1086/391661 
Staves, Susan. “'Books without Which I Cannot Write’: How Did Eighteenth-century Women Writers Get the Books They Read?” Women and Material Culture, 1660-1830. Ed. Jennie Batchelor and Cora Kaplan. New York: Palgrave Macmillan, 2007. 192-211. Print. http://dx.doi.org/10.2307/1769895

---. "Don Quixote in Eighteenth-Century England.” Comparative Literature 24.3 (1972): 193215. Print.

Wortley Montagu, Mary. The Complete Letters of Lady Mary Wortley Montagu. Ed. Robert Halsband. Vol. 3. Oxford: Clarendon P, 1967. Print. 
Appendix A

Proposed Influences on Lennox's The Female Quixote (1752)

- Cervantes, Don Quixote, 1605, 1615

- Shakespeare, The Tempest, 1611

- La Calprenède, Cassandre, 1642-50

- Scudéry, Artaméne, ou le Grand Cyrus, 1648-53

- La Calprenède, Cléopatra, 1648

- Scudéry, Clélie, 1654-61

- Perdou de Subligny, La Fausse Clélie, 1670

- Boyle, Parthenissa, 1676

- La Calprenède, Faramond, 1661

- Fénelon, Traité de l'education des filles, 1687

- $\quad$ Locke, An Essay Concerning Human Understanding, 1690

- $\quad$ Steele, The Tender Husband, 1705

- Marivaux, Don Quixote Moderne, 1737

- Fielding, Joseph Andrews, 1742

- Richardson, Clarissa, 1748

- Johnson, The Rambler, 1750-52

- Fielding, Amelia, 1751 
Appendix B

Works Referred to in Lennox's The Life of Harriot Stuart (1750)

- Chillingworth, The Religion of Protestants a Safe Way of Salvation, 1637

- Scudéry, Clélie, 1654-61

- $\quad$ Lee, The Rival Queens, 1677

- Otway, The Orphan, 1680

- $\quad$ Dryden, The Works of Virgil, 1693

- Prior, “Henry and Emma,” 1709

- Pope, “The Rape of the Lock,” 1714

- Hutcheson, “An Essay on the Nature and Conduct of the Passions and Affections,” 1728 
Appendix C

Additional Writers Named in The Life of Harriot Stuart (1750)

- Homer

- Plato

- Cicero

- Isaac Barrow

- John Tillotson

- Nicholas Rowe 
Appendix D

Complete List of Writers Named in The Life of Harriot Stuart (1750)

- Homer

- Plato

- Cicero

- Chillingworth

- Scudéry

- Isaac Barrow

- John Tillotson

- Lee

- Otway

- Dryden

- Prior

- Pope

- Rowe

- Hutcheson 
Appendix E

Writers With Whom Lennox Was Probably Familiar by 1752

\begin{tabular}{|c|c|}
\hline Homer & Lee \\
\hline Sappho & Otway \\
\hline Plato & Dryden \\
\hline Cicero & Farquhar \\
\hline Ovid & Prior \\
\hline Cervantes & Locke \\
\hline Shakespeare & Steele \\
\hline Chillingworth & Addison \\
\hline La Calprenède & Rowe \\
\hline Scudéry & Marivaux \\
\hline Perdou de Subligny & Pope \\
\hline Boyle & Hutcheson \\
\hline Fénelon & Fielding \\
\hline Barrow & Richardson \\
\hline Tillotson & Johnson \\
\hline
\end{tabular}

